\title{
Screen-printed electrodes for the determination of iridium in drugs
}

Marc Zaguirre, Cristina Ariño*, Núria Serrano, José Manuel Díaz-Cruz and Miquel Esteban

Departament of Chemical Engineering and Analytical Chemistry. Faculty of Chemistry. University of Barcelona. Martí i Franquès, 1-11, E-08028 Barcelona (Spain).

"Corresponding author. Phone: (+34) 9340215 45. Fax: (+34) 9340212 33. E-mail: cristina.arino@ub.edu

\begin{abstract}
Among the impurities that must be controlled in drugs and pharmaceuticals, metal ions are considered. These metal impurities appear in those products because of their use as catalysts. Although Pharmacopeias recommend ICP based methods for their determination, the use of electroanalytical techniques can be considered as a sensible, selective and non-expensive alternative for the determination of heavy metal ions in general and metal impurities in particular. In the present work, we propose a differential pulse voltammetric method based on the use of carbon based-screen-printed electrodes (graphite, nanotubes or nanofibers) that allows the determination of iridium in drugs at the concentration limits recommended by official organisms. Carbon screen-printed electrode modified with nanotubes (CNT-SPCE) is the sensor that provided the best LOD and LOQ (0.03 and $0.10 \mathrm{mg} \mathrm{L}^{-1}$ respectively). Then, the proposed method was applied to the voltammetric determination of iridium in spiked drug samples purchased in local chemists using CNT-SPCE.
\end{abstract}

Keywords: metal impurities, drugs, iridium, voltammetry, screen-printed electrodes 


\section{Introduction}

Organic and inorganic compounds and residual solvents are the three types of impurities that must be controlled in drugs and in their ingredients, and by extension in certain foods and dietary supplements because of their potential toxic effects in humans [1-6]. Inside inorganic impurities, metals like iridium, rhodium, ruthenium and osmium must be considered. These metals, classified as Class 1B by the European Agency for the Evaluation of Medicines (EMEA), can be introduced during the manufacturing process and their concentration must be controlled in the final product as impurities. Table 1 shows the exposure and the concentration limits of different metals according EMEA [2].

To control their presence in drugs and pharmaceutical, methodologies with high sensitivity and selectivity must be developed to substitute the traditional procedures described in all international pharmacopoeias for metal impurities determination that have serious limitations. In this sense, a method used for monitoring inorganic contaminants in drugs is based on a classic colorimetric test described in the USP General Chapter <231> [7]. This method is based on the precipitation of sulfide compounds after reaction with thioacetamide, in which the resulting colored precipitate is compared visually to a $10 \mathrm{mg} \mathrm{L}^{-1} \mathrm{~Pb}$ (II) standard solution to determine compliance with the heavy metal limit concentration. Besides the associated error with the subjective visual comparison, this method is only useful for $\mathrm{Ag}, \mathrm{As}, \mathrm{Bi}, \mathrm{Cd}, \mathrm{Cu}, \mathrm{Hg}, \mathrm{Mo}, \mathrm{Pb}, \mathrm{Sb}$ and $\mathrm{Sn}$. Thus, this method can neither provide selectivity nor give individual concentration of each particular element. In addition, it cannot be used to determine elements like chromium or platinum group elements that are commonly used as catalysts. To solve this problem, USP General Chapter <233> [3] recommends the use of multi-element techniques like inductively coupled plasma mass spectrometry (ICP-MS) and inductively coupled plasma atomic emission spectroscopy (ICP-AES) instead of the colorimetric test described above. Relevant papers devoted to the determination of elemental impurities in pharmaceutical products by ICP based techniques have been published in the last years [6,8-11]. However, the high cost of the required instrumentation appears as the main drawback of these methods. In this point, electroanalytical techniques can be considered as a sensible, selective and non-expensive option for the determination of heavy metals in general and metal impurities in particular. In the literature, a great number of papers devoted to the analysis of some of these analytes have been published [12-16]. In these papers as well as in the works cited therein, a lot of metal ions, matrices and electrodes have been considered. However, the number of works devoted to the determination of elements of platinum group and in particular to iridium was very scarce. Locatelli [17-19] proposes a voltammetric determination method for iridium in natural samples by square wave 
adsorptive-catalytic stripping voltammetry (SWAdCSV) in a glassy carbon electrode at pH 4.8 media containing $\mathrm{NaBrO}_{3}$ and L-1-cetyltrimethylammonium bromide (CTAB) allowing very favorable detection limits. Svancara et al. [20] consider a carbon paste electrode modified with a surfactant for the determination of platinum group elements both in model solution and in real industrial wastewaters. In any case, the use of screen-printed electrodes (SPE) has not been considered for the analysis of iridium. On the other hand, the number of publications considering the use of electroanalytical techniques for the analysis of metal impurities in drugs is very limited, as far as we know, only a work by Guna et al. [21] aims on the development of a potentiometric sensor for the analysis of some metal ions in drugs and pharmaceuticals. In this work, although a great number of metal ions have been considered no reference to iridium appears.

In the present work, a simple voltammetric methodology using carbon based screen-printed electrodes has been proposed for the analysis of iridium in drugs at the levels recommended by official organisms. The screen-printed electrodes considered were a graphite screen-printed electrode (SPCE), a carbon screen-printed electrode modified with carbon nanotubes (CNTSPCE) and a carbon screen-printed electrode modified with nanofibers (CNF-SPCE). The proposed differential pulse voltammetric methodology was applied to the determination of iridium in spiked commercial drugs using a CNT-SPCE as the optimal sensor.

\section{Experimental}

\subsection{Reagents}

$\operatorname{Ir}(\mathrm{IV})$ working solutions were prepared by the appropriate dilutions of an atomic standard solution of $1.000 \mathrm{~g} \mathrm{~L}^{-1}$ of $\operatorname{Ir}(\mathrm{IV})$ from Sigma-Aldrich (St. Louis, USA). Ultrapure sulphuric acid (Merck, Darmstad, Germany) was used to control the pH and as supporting electrolyte.

All solutions were prepared in ultrapure water obtained from a Milli-Q plus 185 system, Millipore.

Adolonta ${ }^{\circledR}$ and Trigon $^{\circledast}$ drug samples were purchased in local chemists.

\subsection{Apparatus}

Cyclic voltammetric (CV) and differential pulse voltammetric (DPV) experiments were performed in a $\mu$ Autolab Type III (Ecochemie, The Netherlands) coupled to a Metrohm 663VA Stand 
(Metrohm, Switzerland) and a personal computer with GPES version 4.9 data acquisition software (Ecochemie).

The electrochemical experiments were carried out using different working electrodes: i) a graphite screen-printed electrode (SPCE) referenced as DRP-110 (DropSens, Oviedo, Spain); ii) a carbon screen-printed electrode modified with carbon nanotubes (CNT-SPCE) referenced as DRP-110CNT (DropSens); and iii) a carbon screen-printed electrode modified with carbon nanofibers (CNF-SPCE) referenced as DRP-110CNF (DropSens). As reference and auxiliary electrodes, external $\mathrm{Ag} / \mathrm{AgCl} / \mathrm{KCl}\left(3 \mathrm{~mol} \mathrm{~L}^{-1}\right)$ and carbon electrodes were respectively used unless otherwise indicated. It should be pointed out that internal reference and auxiliary electrodes of the screen-printed devices were also considered in some of the performed experiments.

\subsection{Voltammetric measurements}

Voltammetric measurements were performed by introducing in the voltammetric cell a certain volume of standard or sample solution in $0.016 \mathrm{~mol} \mathrm{~L}^{-1} \mathrm{H}_{2} \mathrm{SO}_{4}$ media. Instrumental parameters were $50 \mathrm{mV}$ of pulse amplitude with a modulation time of $50 \mathrm{~ms}$ applied at interval times of 0.5 s. The cathodic scan rate applied was from $1.1 \mathrm{~V}$ to $0.35 \mathrm{~V}$. After each measurement, a conditioning potential of $1.1 \mathrm{~V}$ was applied during $30 \mathrm{~s}$ to remove possible residues of iridium from the electrode surface. When measurements were performed in drop (using the threeelectrode cell of the SPE), the measuring solution was prepared in a volumetric flask and a drop of the solution was deposited on the surface of the CNT-SPCE covering the area of the three electrodes. Instrumental parameters were equal to those considered in cell measurements.

\section{3.- Results and discussion}

To characterize the electrochemical redox processes of $\operatorname{Ir}(\mathrm{IV})$ solution, cyclic voltammetric experiments were performed using a SPCE. Figure 1 shows a cyclic voltammogram of $60 \mathrm{mg} \mathrm{L}^{-1}$ Ir(IV) solution in $0.016 \mathrm{~mol} \mathrm{~L}^{-1} \mathrm{H}_{2} \mathrm{SO}_{4}$ media using a scan rate of $100 \mathrm{mV} \mathrm{s}^{-1}$. Scans were performed from $1.2 \mathrm{~V}$ to $-0.5 \mathrm{~V}$ and returned to $1.2 \mathrm{~V}$. Two well-defined cathodic peaks close to $0.8 \mathrm{~V}$ (peak 1) and $0.63 \mathrm{~V}$ (peak 2) were observed together with their respective anodic peaks close to 0.83 $\mathrm{V}$ (peak $1^{\prime}$ ) and $0.70 \mathrm{~V}$ (peak $2^{\prime}$ ), pointing out the reversibility of the redox processes. The cathodic peaks can be attributed to the reduction of $\operatorname{Ir}(\mathrm{IV})$ to $\operatorname{Ir}(\mathrm{III})$ (peak 1 ) and of $\operatorname{Ir}(\mathrm{III})$ to $\operatorname{Ir}(0)$ (peak 2), and the respective anodic ones to the reverse processes (peak $1^{\prime}$ and peak 2'). The analysis of the dependence of the peak current intensity in front of the square root of the scan rate (from $10 \mathrm{mV} \mathrm{s}^{-1}$ to $1000 \mathrm{mV} \mathrm{s}^{-1}$ ) was considered showing a linear relation between both 
parameters which indicates that all the processes are controlled by diffusion (results not shown). Moreover, at potentials from $-0.3 \mathrm{~V}$ and $0.15 \mathrm{~V}$ some small signals are also observed (peaks 3,4 and $3^{\prime}$ ) that can be associated to catalytical signals related with protons $[22,23]$.

Figure 2 shows the differential pulse voltammogram of $40 \mathrm{mg} \mathrm{L}^{-1} \mathrm{Ir}(\mathrm{IV})$ solution in $0.016 \mathrm{~mol} \mathrm{~L}^{-1}$ $\mathrm{H}_{2} \mathrm{SO}_{4}$ media using a SPCE in which two peaks corresponding to the reduction of $\operatorname{Ir}(\mathrm{IV})$ to $\operatorname{Ir}$ (III) (peak 1) and of $\operatorname{Ir}(I I I)$ to $\operatorname{Ir}(0)$ (peak 2) can be observed. With the aim to stablish which of both peaks is the most appropriate for analytical purposes, different studies were performed considering the three screen-printed electrodes above indicated: SPCE, CNT-SPCE and CNFSPCE. The obtained results obtained are shown in Table 2. Reproducibility for each electrode was computed from 5 independent measurements of a $60 \mathrm{mg} \mathrm{L}^{-1} \operatorname{Ir}(\mathrm{IV})$ solution using 5 different units; whereas repeatability was obtained from 10 consecutive measurements of the same solution carried out using the same SPE unit. As it can be seen in this table, reproducibility and repeatability results obtained for each peak at each considered SPE pointed out that peak 1, corresponding to the reduction process of $\operatorname{Ir}(\mathrm{IV})$ to $\operatorname{Ir}(\mathrm{III}$ ), performs better than peak 2 (reduction process of $\operatorname{Ir}(I I I)$ to $\operatorname{Ir}(0))$. Therefore, peak 1 will be further considered for analytical purposes. Moreover, according to the obtained results, it can be concluded that CNT-SPCE would be the more convenient sensor in term of reproducibility and repeatability.

With the aim to establish the optimal concentration range for the determination of $\operatorname{Ir}($ IV), DPV measurements of different solutions containing $\operatorname{Ir}(\mathrm{IV})$ from $0.1 \mathrm{mg} \mathrm{L}^{-1}$ to $100 \mathrm{mg} \mathrm{L}^{-1}$ in $0.016 \mathrm{~mol}$ $\mathrm{L}^{-1} \mathrm{H}_{2} \mathrm{SO}_{4}$ media using the three considered SPEs were performed. Figure $3 a$ shows the obtained voltammograms using a SPCE. Again, it can be observed the presence of two overlapped peaks corresponding to peak 1 and peak 2 . The obtained calibration plot is shown in Figure $3 \mathrm{~b}$. This plot presents two different lineal ranges from 0.1 to $10 \mathrm{mg} \mathrm{L}^{-1}$, and around $10 \mathrm{mg} \mathrm{L}^{-1}$ to $100 \mathrm{mg}$ $\mathrm{L}^{-1}$, being $100 \mathrm{mg} \mathrm{L}^{-1}$ the highest concentration considered. Similar results were observed for the other studied SPEs (results not shown). Taking into account that the interest is related to the determination of $\operatorname{Ir}(\mathrm{IV})$ at low concentrations, in the following the lower linear range will be considered. Thus, linear calibration curves were carried out by DPV using SPCE, CNT-SPCE and CNF-SPCE by measuring increasing concentrations of $\operatorname{Ir}\left(\mathrm{IV}\right.$ ) ranging from 0.1 to $10 \mathrm{mg} \mathrm{L}^{-1}$ (Figure 4). The obtained voltammograms confirm that the peak 1 is the most appropriate for analytical purposes because the height of peak 2 is lower and appears at higher $\operatorname{Ir}(\mathrm{IV})$ concentrations.

Calibration data for the determination of $\operatorname{Ir}($ IV) using SPCE, CNT-SPCE and CNF-SPCE are reported in Table 3. Sensitivities were calculated as the slope of the calibration curves and limits of detection (LOD) and quantification (LOQ) were computed as 3 and 10 times, respectively, the 
standard deviation of the intercept over the slope of the calibration plot. The LOQ was considered as the lowest value of the linear concentration range.

As it can be seen in Table 3, the lowest LOD was achieved using a CNT-SPCE. Although CNF-SPCEs usually provide better LODs [23], it must be pointed out that in this study, the baseline obtained with CNF-SPCE shows a great contribution of capacitive currents in comparison to that of the other SPEs considered that leads to higher LODs. From these studies, it can be concluded that taking into account that the objective is to determine low concentrations of $\operatorname{Ir}(\mathrm{IV})$ in drugs and the reproducibility and repeatability results (Table2), the optimal sensor for this aim is a SPCE modified with CNTs.

In order to test the applicability of this methodology to a real drug, the analysis of Ir(IV) was attempted in drug samples purchased in local chemists. The considered drugs were Adolonta ${ }^{\circledR}$ that contains, as active pharmaceutical ingredient (API), tramadol hydrochloride that it is used for the treatment of moderate to severe pain, and Trigon ${ }^{\circledR}$ that contains triamcinolone acetonide as API and it is used as anti-inflammatory drug. For their analysis these samples were previously spiked with $\operatorname{Ir}(\mathrm{IV})$. The level of $\operatorname{Ir}(\mathrm{IV})$ added was evaluated taking into account the recommended dose of the API per day, the recommended limit concentration of iridium per day, and the sample dilution required to obtain the measuring solution in $0.16 \mathrm{~mol} \mathrm{~L}^{-1} \mathrm{H}_{2} \mathrm{SO}_{4}$ media. According to these points, samples of Adolonta ${ }^{\circledR}$ and $\operatorname{Trigon}^{\circledR}$ were spiked with an $\operatorname{Ir}($ IV) concentration that results in $0.666 \mathrm{mg} \mathrm{L}^{-1}$ and $1.333 \mathrm{mg} \mathrm{L}^{-1} \mathrm{~m}$ respectively in the measuring solution. The external calibration method was applied for quantification and the obtained results are shown in Table 4. Proper recoveries were achieved pointing out that this methodology is appropriate for the analysis of $\operatorname{Ir}(\mathrm{IV})$ at these levels of concentration in drugs by DPV in CNT-SPCE. Moreover, this determination was also performed considering the particular properties of SPEs that allow carrying out the determination using only a drop sample since the three electrodes of the electrochemical cell are integrated in the device. The good results obtained considering the drop analysis are also shown in Table 4.

From these studies it can be concluded that CNT-SPCEs are very suitable for the determination of $\operatorname{Ir}(\mathrm{IV})$ in drug samples by DPV at the concentration levels between 0.10 and $10 \mathrm{mg} \mathrm{L}^{-1}$, which has allowed the detection of concentration levels lower than the maximum concentration level recommended per day. 


\section{Conclusions}

In this work the voltammetric determination of $\operatorname{Ir}$ (IV) in drugs using carbon based- SPES (SPCE, CNT-SPCE or CNF-SPCE) was studied as a sensible, selective and non-expensive alternative to ICP based methods. Cyclic voltammetric measurements show that the reversible and diffusion controlled reduction process of $\operatorname{Ir}(\mathrm{IV})$ in a $0.016 \mathrm{~mol} \mathrm{~L}^{-1} \mathrm{H}_{2} \mathrm{SO}_{4}$ media takes place in two steps, first the reduction of $\operatorname{Ir}(\mathrm{IV})$ to $\operatorname{Ir}(\mathrm{III})$ and later the reduction of $\operatorname{Ir}(\mathrm{III})$ to $\operatorname{Ir}(0)$. Studies performed by DPV show that the peak related to the $\operatorname{Ir}(\mathrm{IV})$ to $\operatorname{Ir}(\mathrm{III})$ reduction process is the most appropriate for analytical purposes. Figures of merit of the procedure show that the best sensor is that modified with nanotubes (CNT-SPCE) providing both the lower LOD and LOQ values (0.03 and $0.10 \mathrm{mg} \mathrm{L}^{-1}$ respectively), and the best repeatability and reproducibility. Then, the proposed method was successfully applied to the voltammetric determination of iridium in spiked drug samples purchased in local chemists using a CNT-SPCE, providing good reproducibility and trueness inferred by the RSD and the relative error respectively.

\section{Acknowledgements}

This work has been supported by the Generalitat of Catalonia (Project 2017SGR311).

\section{References}

1. D.R. Abernethy, A.J. DeStefano, T.L. Cecil, K. Zaidi, R.L. Williams and the USP Metal Impurities Advisory Panel, Pharm. Research 2010, 27, 750-755.

2. Guideline on the specification limits for residues of metal catalysts or metal reagents (EMEA/CHMP/SWP/4446/2000). Committee for medical products for human use (CHMP) European Medicine Agency. London. February 2008.

3. Elementary impurities - Procedures. Pharm. Forum, 2010, 37(3) Chapters $\langle 232\rangle$ and $\langle 233\rangle$.

4. ICH Expert Working Group. Guideline for elemental impurities. ICH harmonized guideline Q3D. December 2014.

5. V. Balaram, TrAC - Trends Anal. Chem. 2016, 80, 83-95.

6. U. Wollein, B. Bauer, R. Habernegg, N. Schramek, Eur. J. Pharm. Sci. 2015, 77, 100-105.

7. Elementary impurities - Procedures. Pharm. Forum, 2011, 37(3) Chapters <231>.

8. M. Mittal, K. Kumar, D. Anghore, R.K. Rawal, Curr. Drug Disc. Tech. 2017, 14, 106-120. 
9. J.S. Barin, P.A. Mello, M.F. Mesko, F.A. Duarte, E.M.M. Flores, Anal. Bioanal. Chem. 2016, 408, 4547-4566.

10. A.L.H. Muller, J.S.S. Oliveira, P.A. Mello, E.I. Muller, E.M.M. Flores, Talanta 2015, 136, 161 169.

11. O. Chahrour, J. Malone, M. Collins, V. Salmon, C. Greenan, A. Bombardier, Z. Ma, N. Dunwoody, J. Pharm. Biomed. Anal. 2017, 145, 84-90.

12. C. Ariño, N. Serrano, J.M. Díaz-Cruz, M. Esteban, Anal. Chim. Acta 2017, 990, 11-53.

13. V. Jovanovski, S.B. Hocevar, B. Ogorevc, Electroanalysis 2009, 21, 2321-2324.

14. G. Aragay, J. Pons, A. Merkoçi, Chem. Rev. 2011, 111, 3433-3458.

15. K.C. Honeychurch, J.P. Hart, Trac-Trends Anal. Chem. 2003, 22, 456-469.

16. J. Barton, M.B. González García, D. Hernández Santos, P. Fanjul-Bolado, A. Ribotti, M. McCaul, D. Diamond, P. Magni, Microchim. Acta 2016, 183, 503-517.

17. C. Locatelli, Microchem. J. 2013, 106, 282-288.

18. C. Locatelli, Talanta 2011, 85, 546-550.

19. C. Locatelli, Electroanalysis 2011, 23, 1329-1336.

20. I. Švancara, M. Galík, K. Vytřas, Talanta 2007, 72, 512-518.

21. R.N. Guna, J.M. Vyas, A. Ramkishan, Y.K. Agrawal, Rev. Anal. Chem. 2012, 31, 193-199.

22. M. Kolodziej, I. Baranowska, A. Matyja, Electroanalysis 2007, 19, 1585-1589.

23. A. M. Demkin, J. Anal. Chem. 2001, 56, 1051-1056.

24. C. Pérez-Ràfols, N. Serrano, J.M. Díaz-Cruz, C. Ariño, M. Esteban, Anal. Chim. Acta 2016, 916, 17-23. 
Table 1. Classification and recommended limits of concentration of elemental impurities [2].

\begin{tabular}{|c|c|c|c|c|c|}
\hline \multirow[t]{2}{*}{ Classification } & \multicolumn{2}{|c|}{ Oral exposure } & \multicolumn{2}{|c|}{ Parental exposure } & \multirow{2}{*}{$\begin{array}{r}\begin{array}{r}\text { Inhalat } \\
\text { exposI }\end{array} \\
\begin{array}{r}\text { PDE } \\
\text { (ng per }\end{array}\end{array}$} \\
\hline & $\begin{array}{c}\text { PDE }^{* * *} \\
\text { ( } \mu \mathrm{g} \text { per day) }\end{array}$ & $\begin{array}{c}\text { Concentration } \\
\left(\mathrm{mg} \mathrm{L}^{-1}\right)\end{array}$ & $\begin{array}{c}\text { PDE } \\
\text { ( } \mu \text { g per day) }\end{array}$ & $\begin{array}{c}\text { Concentration } \\
\left(\mathrm{mg} \mathrm{L}^{-1}\right)\end{array}$ & \\
\hline Class 1A: Pt, Pd & 100 & 10 & 10 & 1 & Pt: $7 C$ \\
\hline $\begin{array}{c}\text { Class 1B: }{ }^{* *} \text { Ir, Ru, } \\
\text { Rh, Os }\end{array}$ & 100 & 10 & 10 & 1 & \\
\hline $\begin{array}{c}\text { Class 1C: Mo, Ni, } \\
\text { Cr, } \mathbf{V} \\
\text { Metals with } \\
\text { significant safety } \\
\text { control } \\
\end{array}$ & 250 & 25 & 25 & 2.5 & $\begin{array}{l}\mathrm{Ni}: 1 \mathrm{C} \\
\mathrm{Cr}(\mathrm{IV}):\end{array}$ \\
\hline $\begin{array}{c}\text { Class 2: } \mathrm{Cu}, \mathrm{Mn} \\
\text { Metals with low } \\
\text { safety concern } \\
\end{array}$ & 2500 & 250 & 250 & 25 & \\
\hline $\begin{array}{l}\text { Class 3: Fe, Zn } \\
\text { Metals with minimal } \\
\text { safety concern }\end{array}$ & 13000 & 1300 & 1300 & 130 & \\
\hline
\end{tabular}


Table 2.- Reproducibility and repeatability obtained measuring a solution of $60 \mathrm{mg} \mathrm{L}^{-1}$ of $\operatorname{Ir}(\mathrm{IV})$ in $0.016 \mathrm{~mol} \mathrm{~L}^{-1} \mathrm{H}_{2} \mathrm{SO}_{4}$ media by DPV using the SPCE, CNT-SPCE and CNF-SPCE.

\begin{tabular}{|l|l|l|l|l|l|l|}
\hline \multicolumn{2}{|c|}{} & \multicolumn{2}{l}{ SPCE } & \multicolumn{2}{l|}{ CNT-SPCE } & \multicolumn{2}{l|}{ CNF-SPCE } \\
\cline { 2 - 7 } & Peak 1 & Peak 2 & Peak 1 & Peak 2 & Peak 1 & Peak 2 \\
\hline $\begin{array}{l}\text { Reproducibility } \\
\text { (RSD \%) }\end{array}$ & 6 & 10 & 1 & 4 & 5 & 10 \\
\hline $\begin{array}{l}\text { Repeatability } \\
\text { (RSD \%) }\end{array}$ & 5 & 8 & 2 & 1 & 2.5 & 4 \\
\hline
\end{tabular}


Table 3.- Calibration data, obtained by DPV using SPCE, CNT-SPCE and CNF-SPCE.

\begin{tabular}{|c|c|c|c|c|c|}
\hline $\begin{array}{l}\text { Working } \\
\text { electrode }\end{array}$ & Calibration plot ${ }^{\mathrm{a}}$ & $\mathbf{R}^{2}$ & LOD (mg L-1) & LOQ (mg L $\left.{ }^{-1}\right)$ & $\begin{array}{l}\text { Concentration } \\
\text { range }\left(\mathrm{mg} \mathrm{L}^{-1}\right)\end{array}$ \\
\hline SPCE & $y=-0.1332 x+0.0072$ & 0.9945 & 0.05 & 0.15 & $0.15-10$ \\
\hline CNT-SPCE & $y=-0.1136 x+0.0214$ & 0.9939 & 0.03 & 0.10 & $0.10-10$ \\
\hline CNF-SPCE & $y=-0.1321 x+0.0374$ & 0.9997 & 0.14 & 0.48 & $0.48-10$ \\
\hline
\end{tabular}

${ }^{a} y$ peak current in $\mu \mathrm{A}$ and $\mathrm{x} \operatorname{Ir}(\mathrm{IV})$ concentration in $\mathrm{mg} \mathrm{L}^{-1}$ 
Table 4.- Results obtained in the analysis of drugs spiked with $\operatorname{Ir}(\mathrm{IV})$. Measurements performed by DPV using CNT-SPCE as working electrode in cell or in drop. Standard deviation are denoted by parenthesis $(n=3)$.

\begin{tabular}{|c|c|c|c|}
\hline Adolonta $^{\circledR}$ & & Expected & Found \\
\hline \multirow[t]{3}{*}{ In cell } & $c\left(\mathrm{mg} \mathrm{L}^{-1}\right)$ & 0.666 & 0.68 \\
\hline & RSD (\%) & -- & 6.1 \\
\hline & Relative error (\%) & -- & 1.7 \\
\hline \multirow[t]{3}{*}{ In drop } & $c\left(m g ~ L^{-1}\right)$ & 0.666 & 0.68 \\
\hline & RSD (\%) & -- & 3.4 \\
\hline & Relative error (\%) & -- & 1.6 \\
\hline Trigon $^{\circledR}$ & & Expected & \\
\hline \multirow[t]{3}{*}{ In cell } & $\mathrm{c}\left(\mathrm{mg} \mathrm{L}^{-1}\right)$ & 1.333 & 1.32 \\
\hline & RSD (\%) & -- & 6.5 \\
\hline & Relative error (\%) & -- & 1.3 \\
\hline \multirow[t]{3}{*}{ In drop } & $c\left(\mathrm{mg} \mathrm{L}^{-1}\right)$ & 1.333 & 1.32 \\
\hline & RSD (\%) & -- & 5.05 \\
\hline & Relative error (\%) & - & 1.07 \\
\hline
\end{tabular}


Figure 1.- Cyclic voltammogram of a $60 \mathrm{ppm} \operatorname{~Ir(IV)~solution~in~a~} 0.016 \mathrm{~mol} \mathrm{~L}^{-1} \mathrm{H}_{2} \mathrm{SO}_{4}$ media measured with a SPCE. Scan rate $100 \mathrm{mV} \mathrm{s}^{-1}$.

Figure 2.- Differential pulse voltammogram of a $20 \mathrm{ppm} \operatorname{Ir}(\mathrm{IV})$ solution in a $0.016 \mathrm{~mol} \mathrm{~L}^{-1} \mathrm{H}_{2} \mathrm{SO}_{4}$ media measured with a SPCE.

Figure 3.- a) Peak current vs. Ir(IV) concentration plot, and b) voltammograms measured at increasing $\operatorname{Ir}(\mathrm{IV})$ concentration from 0.04 to $100 \mathrm{ppm}$ in a $0.016 \mathrm{~mol} \mathrm{~L}^{-1} \mathrm{H}_{2} \mathrm{SO}_{4}$ media measured with a SPCE.

Figure 4.- Differential pulse voltammograms of $\operatorname{Ir}(\mathrm{IV})$ solutions from 0.04 to $10 \mathrm{ppm}$ measured with SPCE, CNT-SPCE and CNF-SPCE in a $0.016 \mathrm{~mol} \mathrm{~L}^{-1} \mathrm{H}_{2} \mathrm{SO}_{4}$ media. Insets show the corresponding calibration plots. 
Figure 1

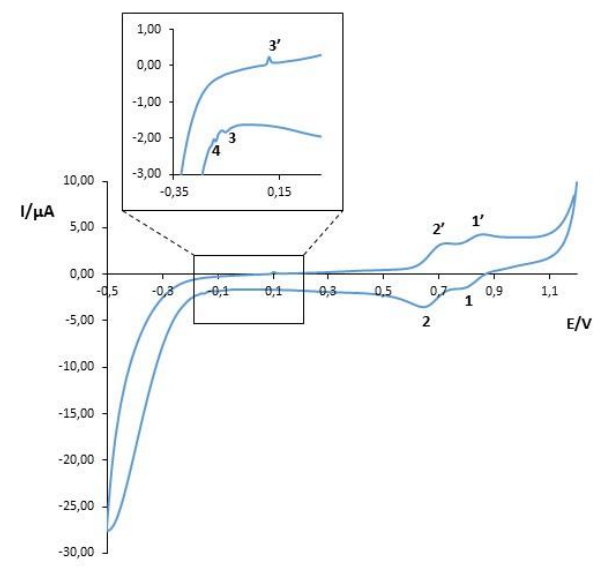


Figure 2

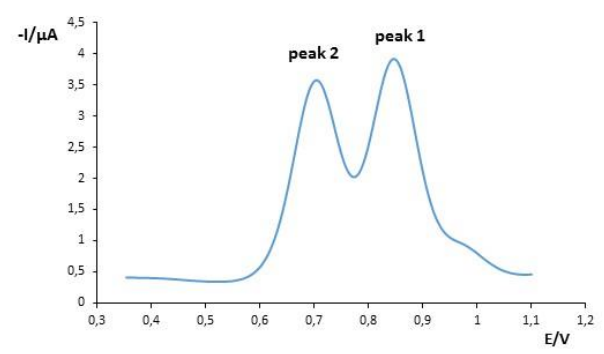


Figure 3
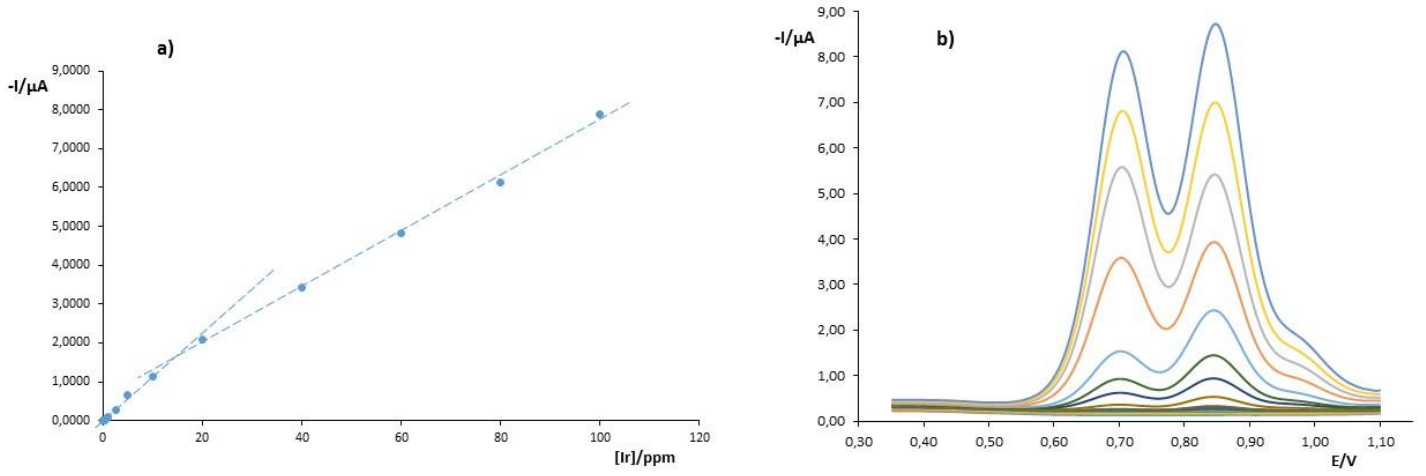
Figure 4

SPCE

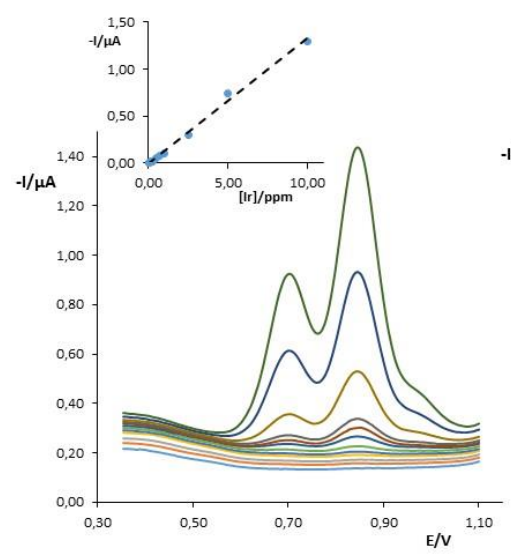

CNT-SPCE

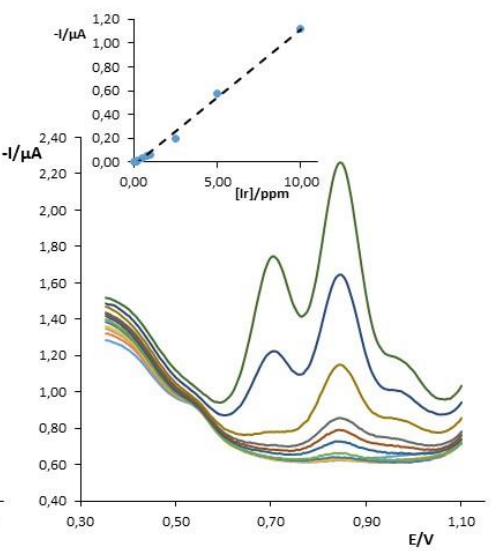

CNF-SPCE

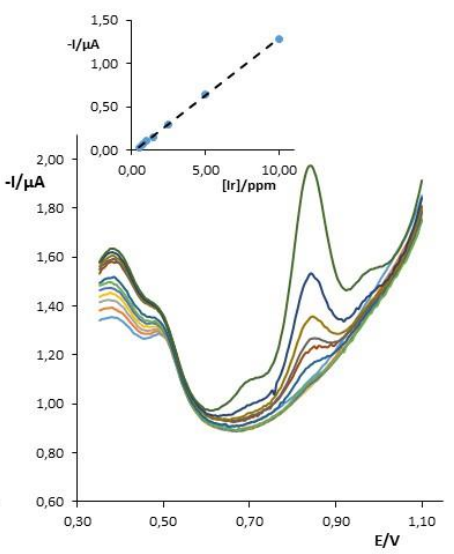

